\title{
Longterm outcome after injection sclerotherapy for oesophageal varices in children with extrahepatic portal hypertension
}

\author{
M D Stringer, E R Howard
}

\begin{abstract}
A consecutive series of 36 children with bleeding from oesophageal varices secondary to extrahepatic portal hypertension was successfully treated by endoscopic injection sclerotherapy and followed up over a mean period of 8.7 years after variceal obliteration. There were no deaths from portal hypertension or its treatment and morbidity related to oesophageal sclerotherapy was minimal. Endoscopic injection sclerotherapy alone proved safe and effective in controlling variceal bleeding from portal hypertension in over $80 \%$ of the children. Recurrent variceal bleeding developed in $10(31 \%)$ patients but half of these were effectively treated by further sclerotherapy. Gastric variceal bleeding unresponsive to sclerotherapy necessitated successful portosystemic shunt surgery in four (13\%) patients. Two children required splenectomy for painful splenomegaly. In most children injection sclerotherapy is the best treatment for the primary management of bleeding oesophageal varices, reserving portosystemic shunting or other surgical procedures for those with bleeding from gastrointestinal varices.

(Gut 1994; 35: 257-259)
\end{abstract}

Bleeding from oesophageal varices is the commonest cause of serious gastrointestinal haemorrhage in children and is associated with a death rate of $5-9 \%$ in those with portal vein obstruction and a considerably greater morbidity and mortality in children with cirrhosis.' Opinions on the primary management of this condition have long been divided between those who advocate portosystemic shunting ${ }^{2-5}$ and those who favour endoscopic injection sclerotherapy. ${ }^{6-10}$ The published results of endoscopic injection sclerotherapy in large numbers of children with oesophageal varices have recently encouraged the widespread acceptance of the technique ${ }^{10-13}$ but there is little information on the longterm results. While this may be less important for those with primary intrahepatic disease, in whom prognosis is largely determined by underlying liver pathology, such data are essential for those with portal vein obstruction in whom variceal bleeding is the main threat to life.

We therefore reviewed a cohort of children who had previously had injection sclerotherapy for bleeding oesophageal varices secondary to extrahepatic portal hypertension.

Patients and Methods

In 1988, we reported the initial results of endo- scopic injection sclerotherapy for bleeding oesophageal varices in a consecutive series of 36 children with portal vein obstruction. ${ }^{8}$ Mean age at onset of variceal bleeding was 5 years and 10 patients had previously had a variety of unsuccessful surgical procedures for portal hypertension. Oesophageal varices were successfully obliterated by injection sclerotherapy in all cases without death and within a mean period of less than one year.

Subsequent surveillance endoscopies were performed at six month to two yearly intervals. Small asymptomatic lower oesophageal and contiguous fundal varices were injected with small volumes of sclerosant. Patients who developed gastrointestinal bleeding from portal hypertension despite obliteration of oesophageal varices had arterioportography to define portal venous anatomy.

\section{Results}

Four patients were lost to follow up after successful treatment of oesophageal varices and have been excluded from further analysis. The remaining 32 patients ( 21 males, 11 females) have a current mean age of $17 \cdot 2(6 \cdot 8-26 \cdot 7)$ years and have been under review for a mean period of $8 \cdot 7(3 \cdot 7-12 \cdot 8)$ years since variceal obliteration. (Figure)

\section{MORTALITY}

One 8 year old boy died from a myocardial infarction associated with an anomalous left coronary artery, six years after successful treatment of his varices.

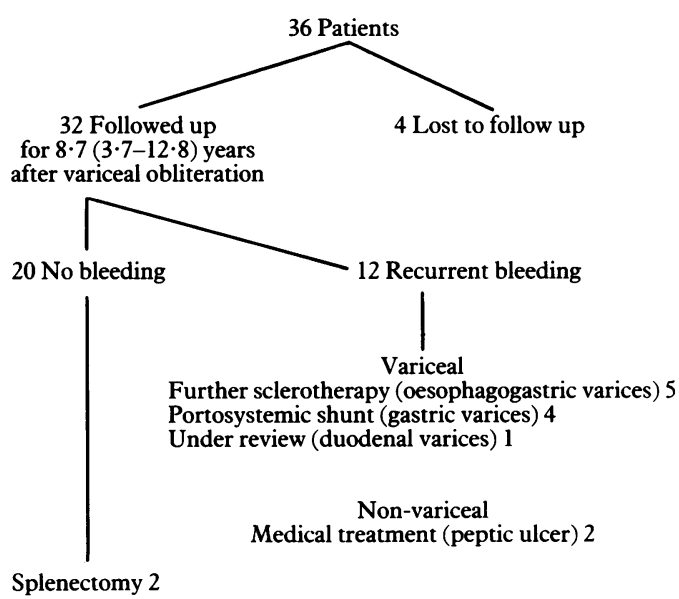

Summary of longterm outcome after endoscopic injection sclerotherapy.
King's College Hosp London

E R Howard

Correspondence to:

Department of Surgery, Firm

III Office, King's College

London SE5 9RS.

Accepted for publication

8 June 1993 
RECURRENT BLEEDING

Recurrent gastrointestinal bleeding occurred in 12 patients but was a result of peptic ulceration in two who were successfully treated with drugs. Five children, including one who defaulted from follow up, developed melaena or haematemesis, or both due to recurrent oesophagogastric varices, which were controlled by further sclerotherapy. Four patients required portosystemic shunting for bleeding gastric varices unresponsive to injection sclerotherapy, one of whom had previously bled from jejunal ulcers associated with a neonatal duodenojejunostomy for duodenal atresia. One 11 year old boy with a history of a single minor recurrent bleeding episode has an erythematous patch of mucosa in the duodenum associated with duodenal varices; this lesion has been injected once and he remains under observation. Four of these 12 children had multiple sites of gastrointestinal bleeding; the boy with jejunal ulceration and gastric varices and three who required a variety of local treatments for bleeding anorectal varices. ${ }^{14}$

\section{LONGTERM SCLEROTHERAPY COMPLICATIONS}

Oesophageal strictures associated with the initial sclerotherapy course did not recur. ${ }^{8}$ One child developed mild dysphagia after injections at surveillance endoscopies and this responded to a single oesophageal dilatation and two other patients have mild asymptomatic reflux oesophagitis detected at endoscopy.

\section{SURGICAL PROCEDURES}

Sixteen patients were studied by angiography, 14 after completion of sclerotherapy, of whom nine were found to have isolated portal vein occlusion whereas five had additional splenic and superior mesenteric venous thrombosis. Two children had angiography before sclerotherapy, one of whom had thrombosis/collateralisation of both the splenic and main portal veins. Six patients required surgery for complications of portal hypertension (Table). Mesocaval shunts were constructed using autologous internal jugular vein and all patients are currently well with patent shunts.

\section{GENERAL PROGRESS}

Four patients had a history of inguinal herniotomy (bilateral in two), which may reflect an increased intra-abdominal pressure from splenomegaly. Of those who have not had portosystemic shunting or splenectomy, half have

Surgery for complications of portal hypertension

\begin{tabular}{|c|c|c|c|c|}
\hline Patients & $\begin{array}{l}\text { Age } \\
(y)\end{array}$ & Sex & $\begin{array}{l}\text { Indication for } \\
\text { surgery }\end{array}$ & Operation \\
\hline 1 & 14 & $\mathbf{M}$ & Bleeding gastric varices & $\begin{array}{l}1 \text { Gastric transection } \\
2 \text { Mesocaval shunt }\end{array}$ \\
\hline 2 & 5 & $\mathbf{M}$ & Bleeding gastric varices & Mesocaval shunt \\
\hline 3 & 8 & $\mathbf{M}$ & $\begin{array}{l}\text { Hypersplenism and splenic pain (no } \\
\text { bleeding) }\end{array}$ & Splenectomy and lienorenal shunt \\
\hline 4 & 12 & $\mathbf{M}$ & Jejunal ulceration & $\begin{array}{l}1 \text { Lienorenal shunt } \\
2 \text { Anastomotic resection }\end{array}$ \\
\hline $\begin{array}{l}5 \\
6\end{array}$ & $\begin{array}{l}14 \\
22\end{array}$ & $\begin{array}{l}\mathbf{M} \\
\mathbf{M}\end{array}$ & $\begin{array}{l}\text { Bleeding gastric varices } \\
\text { Bleeding gastric varices } \\
\text { Recurrent splenic pain }\end{array}$ & $\begin{array}{l}\text { Mesocaval shunt } \\
\text { Mesocaval shunt } \\
\text { Splenectomy }\end{array}$ \\
\hline
\end{tabular}

persistent thrombocytopenia (<100 $\left.\times 10^{9} \mathrm{l}\right)$ and comparative leucopenia pointing to hypersplenism. Data on height and weight were available for 26 children and were unremarkable except that 9 of 19 boys had heights above the 90th centile.

Of 15 patients over 18 years, 12 are in full time employment and two have had children.

\section{Discussion}

The efficacy of endoscopic injection sclerotherapy in controlling bleeding from oesophageal varices is well established. ${ }^{13}$ The technique is widely used in treating variceal haemorrhage in patients with cirrhosis, although its role in the management of patients with extrahepatic portal hypertension remains controversial. In children, there is scant information on the longterm morbidity of oesophageal sclerotherapy and on the subsequent incidence of bleeding from gastrointestinal or recurrent oesophageal varices. Children with portal vein occlusion, in whom liver function is essentially normal, best exemplify the longterm problems associated with portal hypertension. This study has reviewed a cohort of such patients who have been followed up into adulthood over a mean period of nine years.

There were no deaths from portal hypertension or its treatment and minimal morbidity related to oesophageal sclerotherapy. We found no angiographic evidence to support the suggestion that splenic or mesenteric venous occlusion occurs in a significant proportion of patients with portal vein obstruction as a result of sclerotherapy. ${ }^{15}$ Although 5 of $14(36 \%)$ children showed evidence of extensive mesenteric venous occlusion, angiography was only carried out in our more complicated patients and other authors have identified concomitant splenic or superior mesenteric venous occlusion, or both in more than $20 \%$ of children with extrahepatic portal hypertension when first investigated. ${ }^{16} 17$ It is noteworthy that Rice et $a l,{ }^{18}$ using detailed duplex Doppler sonography in adults with cirrhosis and oesophageal varices, were unable to show any evidence of splenic vein thrombus after sclerotherapy. The potential longterm risk of neoplasia from childhood sclerotherapy remains a concern but despite the global application of this technique in patients with portal hypertension, there are only a few isolated reports of this association. ${ }^{19}$ Moreover, recognised risk factors for oesophageal cancer have coexisted in these adults and a recent systematic study using brush cytology failed to support an association with neoplasia. ${ }^{20}$ Nevertheless, both the longterm efficacy and morbidity of sclerotherapy must remain under review.

Recurrent variceal bleeding developed in 10 (31\%) patients but half of these were effectively controlled by further sclerotherapy. Gastric variceal bleeding not amenable to sclerotherapy necessitated portosystemic shunt surgery in four (13\%) patients. In recent years we have preferred the mesojugular-caval shunt, which confers the best chance of longterm patency and the lowest incidence of rebleeding. ${ }^{2122}$ Bleeding from anorectal varices was successfully treated by 
injections and banding but we have recently encountered one child with portal vein obstruction, who was not a member of this cohort, who required portosystemic shunting for intractable rectal bleeding.

Splenectomy was necessary in two patients because of painful splenomegaly. In several older patients the degree of splenomegaly has spontaneously decreased, probably indicating the development of native portosystemic collaterals. ${ }^{7623}$ This is consistent with the finding that in childhood extrahepatic portal hypertension there is a tendency to a decreased incidence of bleeding in early adulthood. ${ }^{24}$

During a mean follow up period of nine years endoscopic injection sclerotherapy alone proved safe and effective in controlling variceal bleeding from portal hypertension in over $80 \%$ of our children with portal vein occlusion. These results support our previous conclusion that in most children injection sclerotherapy is the best treatment for the primary management of bleeding oesophageal varices. ${ }^{8}$ Nevertheless, almost $20 \%$ of patients have required surgery, either splenectomy for symptomatic splenomegaly or portosystemic shunting for gastrointestinal variceal bleeding. When possible, shunt surgery is effective in such situations and the technical results of portosystemic shunting in extrahepatic portal hypertension have continued to improve. ${ }^{512172225}$ The longterm management of children with portal vein occlusion demands the use of a variety of complementary techniques each of which may be limited by applicability, efficacy, and longterm complications. Our current policy is to control oesophageal variceal bleeding by injection sclerotherapy. We reserve portosystemic shunting for those with bleeding from gastrointestinal varices and devascularisation, transection or direct suture for the same problem in the rare child where shunting is not possible. $^{26}$

1 Mowat AP. Prevention of variceal bleeding. $\mathcal{F}$ Pediatr Gastroenterol Nutr 1986; 5: 679-87.

2 Bismuth H, Franco D, Alagille D. Portal diversion for portal hypertension in children. Ann Surg 1980; 192: 18-24.

3 Alvarez F, Bernard O, Brunelle F, Hadchouel P, Odievre $M$ Alagille D. Portal obstruction in children. II. Results of surgical portosystemic shunts. $\mathcal{F}$ Pediatr 1983; 103: 703-7.
4 Heloury Y, Valayer J, Hay JM, Gauthier F, Alagille D. Hypertension portale chez l'infant. Chir Pediatr 1986; 27: 143-7.

5 Pande GK, Reddy VM, Kar P, Sahni P, Berry M, Tandon BN, et al. Operations for portal hypertension due to extrahepatic obstruction: results and 10 year follow-up. $B M \mathcal{F} 1987 ; 295$ : 1115-7.

6 Stamatakis JD, Howard ER, Psacharopoulos HT, Mowat AP Injection sclerotherapy for oesophageal varices in children. Brf Surg 1982; 69: 74-5.

7 Paquet KJ. Ten years experience with paravariceal injection sclerotherapy of esophageal varices in children. $\mathcal{f}$ Pediatr Surg 1985; 20: 109-12.

8 Howard ER, Stringer MD, Mowat AP. Assessment of injection sclerotherapy in the management of 152 children injection sclerotherapy in the management of 152 chil
with oesophageal varices. $B r \mathcal{F}$ Surg 1988; 75: 404-8.

9 Hassall E, Berquist WE, Ament ME, Vargas J, Dorney S. Sclerotherapy for extrahepatic portal hypertension in childhood. F Pediatr 1989; 115: 69-74.

10 Hill ID, Bowie MD. Endoscopic sclerotherapy for control of bleeding varices in children. Am F Gastroenterol 1991; 86: 472-6.

11 Dilawari JB, Chawla YK, Ramesh GN, Mitra SK, Walia BN. Endoscopic sclerotherapy in children. $\mathcal{F}$ Gastroenterol Hepatol 1989; 4: 155-60.

12 Maksoud JG, Goncalves MEP, Porta G, Miura I, Velhote MCP. The endoscopic and surgical management of portal hypertension in children: analysis of 123 cases. $\mathcal{F}$ Pediatr Surg 1991; 26: 178-81.

13 Stringer MD, Howard ER. The role of endoscopic injection sclerotherapy in the management of portal hypertension in
children. In: Howard ER, ed. Surgery of liver disease in children. In: Howard ER, ed. Surgery of liver disease in

children. Oxford: Butterworth-Heinemann, 1991: 157-70.
4 Heaton ND, Davenport M, Howard ER. Symptomatic Heaton ND, Davenport $M$, Howard ER. Symptomatic
haemorrhoids and anorectal varices in children with portal hypertension. F Pediatr Surg 1992; 27: 833-5.

5 Warren WD, Henderson JM. Endoscopic sclerotherapy for oesophageal varices in children. Br f Surg 1988; 75: 1045

16 Alvarez F, Bernard O, Brunelle F, Hadchouel P, Odievre M, Alagille D. Portal obstruction in children. I. Clinical investigation and haemorrhage risk. F Pediatr 1983; 103: 696-702.

17 Bismuth H, Farges O, Portal hypertension in children. In: Blumgart $\mathrm{LH}$, ed. Surgery of the liver and biliary tract. London: Churchill Livingstone, 1988: 1403-9.

18 Rice S, Lee KP, Johnson MB, Korula J, Ralls PW. Portal venous system after portosystemic shunts or endoscopic venous system after portosystemic shunts or endoscopic 1991; 156: 85-9.

19 Kokudo N, Sanio K, Umekita N, Harihara Y, Tada Y, Idezuki Y. Squamous cell carcinoma after endoscopic injection sclerotherapy for esophageal varices. $A m \mathcal{F}$ Gastroenterol 1990; 85: 861-4.

20 Dina R, Cassisa A, Baroncini D, D'Imperio N. Role of esophageal brushing cytology in monitoring patients treated with sclerotherapy for esophageal varices. Acta Cytol 1992; 36: 477-9.

21 Heaton ND, Howard ER. Complications of portal hypertension. In: Howard ER, ed. Surgery of liver disease in children. Oxford: Butterworth-Heinemann, 1991: 181-90.

22 Valayer J. Portosystemic shunt surgery. In: Howard ER, ed. Surgery of liver disease in children. Oxford: ButterworthSurgery of liver disease in

23 Dilawari JB, Chawla YK. Spontaneous (natural) splenoadrenorenal shunts in extrahepatic portal venous obstrucadrenorenal shunts in extrahepatic portal venous

24 Webb LJ, Sherlock S. The aetiology, presentation and natural history of extrahepatic portal venous obstruction. $Q \mathcal{F ~ M e d}$ 1979; 48: 627-39.

25 Mitra SK, Rao KLN, Narasinham KL, Dilawari JB, Batra BR, Chawla YK, et al. Side-to-side lienorenal shunt without splenectomy in nonicrrhotic portal hypertension in children. f Pediatr Surg 1993; 28: 398-402.

26 Heaton ND, Howard ER Complications and limitations of injection sclerotherapy in portal hypertension. Gut 1993; 34: $7-10$. 